\title{
New records of millipedes (Diplopoda) from caves in Crimea and the Caucasus
}

\section{Sergei I. Golovatch ${ }^{1}$, Ilya S. Turbanov ${ }^{2,3}$, Sergei A. Kapralov ${ }^{4}$, Polina V. Somchenko ${ }^{5}$, Anastasya A. Turbanova ${ }^{1,2}$}

\author{
${ }^{I}$ Institute for Problems of Ecology and Evolution, Russian Academy of Sciences, Leninsky pr. 33, \\ Moscow 119071 Russia. E-mail: sgolovatch@yandex.ru \\ ${ }^{2}$ I.D. Papanin Institute of the Biology of Inland Waters, Russian Academy of Sciences, Borok, \\ Yaroslavl Region,152742 Russia.E-mail: turba13@mail.ru \\ ${ }^{3}$ Cherepovets State University, Cherepovets, Vologda Region, 162600 Russia. \\ ${ }^{4}$ K. Minin Nizhny Novgorod State Pedagogical University, Nizhny Novgorod, 603000 Russia. E- \\ mail: gdgpsnew@gmail.com \\ ${ }^{5}$ Russian Geographical Society, Krasnodar regional branch, Krasnodar, 350033 Russia. E-mail: \\ pv_som@mail.ru
}

ABSTRACT. The results of a taxonomic treatment of Diplopoda collected recently in caves of Crimea and the Caucasus are presented. They concern at least 21 species from nine families and five orders. New faunistic information is provided, allowing for the distribution of a number of millipede species to be considerably refined. Problems of their ecological classification in relation to cavernicoly are discussed.

How to site this article: Golovatch S.I., Turbanov I.S., Kapralov S.A., Somchenko P.V., Turbanova A.A. 2021. New records of millipedes (Diplopoda) from caves in Crimea and the Caucasus // Invert. Zool. Vol.18. No.2. P.85-94. doi: 10.15298/invertzool.18.2.03

KEY WORDS: Myriapoda, cave fauna, trogloxene, eutroglophiles, subtroglophiles, troglobiont, Russia, Abkhazia.

\section{Новые находки двупарноногих многоножек (Diplopoda) в пещерах Крыма и Кавказа}

\section{С.И. Головач ${ }^{1}$, И.С. Турбанов ${ }^{2,3}$, С.А. Капралов ${ }^{4}$, П.В. Сомченко А.А. Турбанова ${ }^{1,2}$}

\footnotetext{
${ }^{1}$ Институт проблем экологии и эволючии РАН, Ленинский пр., 33, Москва 119071 Россия. E-mail: sgolovatch@yandex.ru

${ }^{2}$ Институт биологии внутренних вод им. И.Д. Папанина РАН, Борок, Ярославская обл., 152742 Россия. E-mail: turba13@mail.ru

${ }^{3}$ Череповецкий государственный университет, Череповеи, Вологодская обл., 162600 Россия.

${ }^{4}$ Нижегородский государственный педагогический университет им. К. Минина, Нижний Новгород, 603000, Россия. E-mail: gdgpsnew@gmail.com

${ }_{5}^{5}$ Русское географическое общество, Краснодарское региональное отделение, Краснодар, 350033, Россия. E-mail: pv_som@mail.ru
}

PЕЗЮМЕ. Представлены результаты фаунистической обработки сборов Diplopoda из пещер Кавказа (Россия, Абхазия) и Крыма, относящихся как минимум 21 виду из девяти семейств и пяти отрядов. В работе содержатся новые сведения, существенно 
дополняющие наши знания о распространении ряда видов диплопод, и обсуждаются вопросы их экологической классификации по отношению к пещерам.

Как цитировать эту статью: Golovatch S.I., Turbanov I.S., Kapralov S.A., Somchenko P.V., Turbanova A.A. 2021. New records of millipedes (Diplopoda) from caves in Crimea and the Caucasus // Invert. Zool. Vol.18. No.2. P.85-94. doi: 10.15298/invertzool.18.2.03

КЛЮЧЕВЫЕ СЛОВА: Муriapoda, пещерная фауна, троглоксен, эвтроглофилы, субтроглофилы, троглобионт, Россия, Абхазия.

\section{Introduction}

Studies on millipedes (Diplopoda) found in caves in the Caucasus and Crimea enjoy a long history and, in addition to being devoted to numerous species descriptions and/or records, a few overviews, both general as components of cave fauna and particular, focusing on diplopods alone (e.g., Golovatch, 1984/85; Barjadze et al., 2015, 2019; Turbanov et al., 2016; Golovatch et al., 2018; etc.). There are also fresh papers dealing with individual taxonomic revisions which partly covered cave-dwelling Diplopoda and their distributions (Antić et al., 2018; Vagalinski, Lazányi, 2018; Antić, Reip, 2020; Evsyukov et al., 2018, 2020; Kokhia, Golovatch, 2020; etc.).

The present contribution considers millipedes recorded from caves of the Caucasus (Russia and Abkhazia) and Crimea, based on recent collections. Each new record is accompanied by remarks on the biogeographic and ecological status of the species concerned.

\section{Material and methods}

The material underlying the paper was collected by authors during the last decade, between 2011 and 2020. The samples are stored in $95 \%$ ethanol, currently being shared between the collections of the Zoological Museum of Moscow University (ZMUM) and the private collection of I. Turbanov (IT), as indicated below. The material representing the order Chordeumatida and, partly, the genus Leucogeorgia Verhoeff, 1930 (Julidae) from Causasian caves is omitted here, to be treated later by Dragan $\check{Z}$. Antić, University of Belgrade - Faculty of Biol- ogy, Institute of Zoology, Belgrade, Serbia, who revised and published the samples of these two groups taken earlier (Antić, Makarov, 2016; Antić et al., 2018). Two samples of Omobrachyiulus Lohmander, 1936 are likewise omitted, to be studied later by Bojan Vagalinski, Institute of Biodiversity and Ecosystem Research, Bulgarian Academy of Sciences, Sofia, Bulgaria. The pictures of live millipedes were taken in the field using an Olympus TG-5 (Olympus Corporation, Japan) or a Ricoh WG-4 (Ricoh Company Ltd, Japan) camera.

\section{Results}

The new records presented below concern at least 21 species of Diplopoda from nine families and five orders. Only a few of the species could not be fully identified in the lack of male samples, but the genera and families they are attributed to, albeit some provisionally so, are likewise important.

\section{Taxonomic part}

Order Polyxenida Lucas, 1840

Family Polyxenidae Lucas, 1840

\section{Propolyxenus argentifer (Verhoeff, 1921)}

MATERIAL. $1 \bigcirc^{7}$ (IT), Russia, Krasnodar Prov., $2 \mathrm{~km} \mathrm{~W}$ of Tuapse, flysch cliff near Kadosh Cape, Pauk Cave, 19.X.2019, P.V. Somchenko leg.

REMARKS. An eastern Mediterranean species known from Iran, Azerbaijan, Armenia, Georgia and Russia, including the Crimean Peninsula (Short et al., 2020). The above sample 
seems to represent the first record of this species from a cave, apparently as a trogloxene.

Order Glomerida Brandt, 1833

Family Glomeridellidae Cook, 1896

?Typhloglomeris spp.

MATERIAL. 2 +o (ZMUM), Abkhazia, Gudauta Distr., Duripsh, Lakerbaya Cave, 27.III. 2017, I.S. Turbanov leg.; 1 juv. (IT), Russia, Krasnodar Prov., Apsheronsky Distr., NE spurs of Lago-Naki Mt. Range, Azish-Tau Ridge, Piketnaya Cave, 24.V.2020, P.V. Somchenko leg.

REMARKS. Even the generic assignment is bound to remain uncertain until $\sigma^{7}$ material has been taken and studied. The samples above seem to be the first records of troglomorphic ?Typhloglomeris Verhoeff, 1898 from caves in Abkhazia, as well as Russia beyond the Sochi region, Krasnodar Province, whence the troglophilic T. caucasica Golovatch, 1975 has repeatedly been reported (Golovatch, 1975, 1981, 1989a; Golovatch, Chumachenko, 2013).

Family Glomeridae Leach, 1815

\section{Hyleoglomeris specialis Golovatch, 1989}

MATERIAL. $1+$ (ZMUM), Russia, Chechnya, Shatoy Distr., $7.7 \mathrm{~km} \mathrm{~S}$ of Ulus-Kert, right bank of Sharo-Argun River, Sayd-Emin (= Sayd-Emin Khyekh) Cave, 18.X.2019, S.A. Kapralov leg.

REMARKS. Endemic to the Caucasus, encountered in Russia, Georgia and Azerbaijan (Golovatch, 1989b). The above sample represents the first record of this species from a cave, apparently as a trogloxene.

Trachysphaera costata (Waga, 1857)

MATERIAL. 2 +o (ZMUM), Abkhazia, Gudauta Distr., Duripsh, Lakerbaya Cave, 27.III.2017, I.S. Turbanov leg.

REMARKS. A Central European to eastern Mediterranean species: Central, Eastern and
Southern Europe, Crimea, the Caucasus, Anatolia, the Near East and northwestern Iran. It has been recorded from the Mangupskaya II (Crimea) and Fanagoriyskaya caves (Krasnodar Prov.)(Golovatch, 1990, 2008, 2010). Above is the first record of this species from a cave in Abkhazia, apparently a troglophile.

Order Polyzoniida Cook, 1895

Family Hirudisomatidae Silvestri, 1896

Hirudisoma roseum (Victor, 1839)

MATERIAL. $1+$ (ZMUM), Russia, Republic of North Ossetia-Alania, Alagir Distr., 2 km S of Tamisk, $0.25 \mathrm{~km}$ from right bank of Ardon River, right bank of Kroygom Stream, SkubiNykhasskaya Cave, entrance part, 25.IX.2020, S.A. Kapralov leg.

REMARKS. Subendemic to the Caucasus: Russia, Abkhazia, Georgia, Azerbaijan and northern Turkey. Once recorded from near the entrance to the Sataplia I Cave, Kutaissi Distr., Georgia (Golovatch et al., 2015). Above is the first record of this species from a cave in Abkhazia, apparently a trogloxene.

Order Julida Brandt, 1833

Family Blaniulidae C.L. Koch, 1847

Nopoiulus (Nopoiulus) kochii (Gervais, 1847) Fig. 1.

MATERIAL. $1 \sigma^{7}, 4$ \&ᄋ (ZMUM), Abkhazia, Sukhum Distr., near Guma, Mikhailovskaya (= Shromskaya, Sukhumskaya, Stalaktitovaya) Cave, 3.IX.2015; 1 O $^{7}$ (ZMUM), Crimea, region of Sevastopol, southern spurs of Mount Foros, Forosskaya Cave, 9.VI.2011; 1 (ZMUM), Crimea, Sevastopol, Mitropolichyi Sady natural border, near Vinogradnyi Cape, unnamed cave with a source, 7.VII.2017; all I.S. Turbanov leg.

REMARKS. An ubiquitous species already reported, apparently as a troglophile, in a number of Crimean and Caucasian caves: referred to as Blaniulus pulchellus (Leach, 1814) in the Boryu-Teshik Cave, Crimea, Ai-Petri karst massif(Pliginsky, 1927); the Taglar Cave, Khojavend Distr., Azerbaijan; the Shirokopokos- 

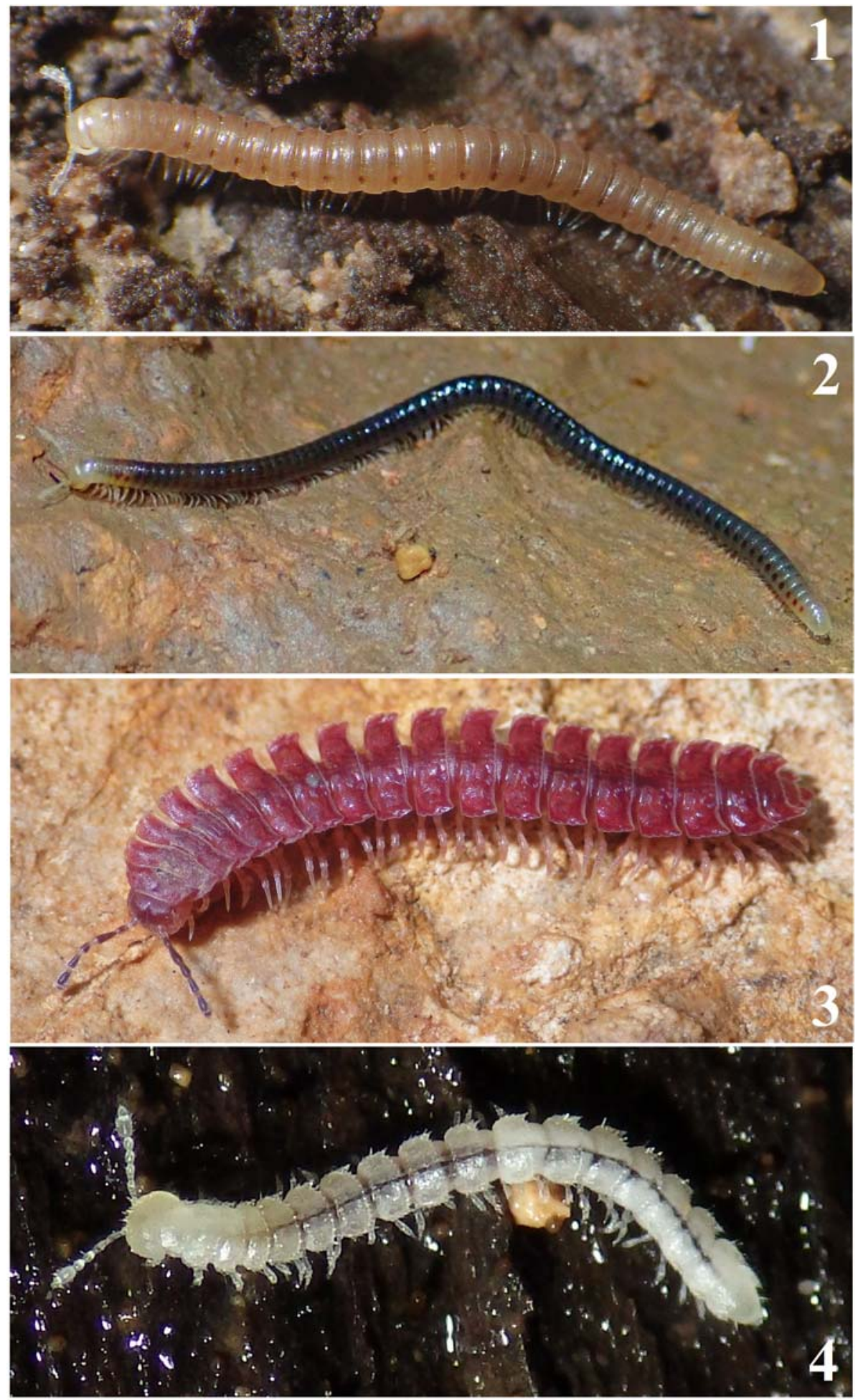
skaya, Bolshaya Kazatshebrodskaya and Malaya Kazatshebrodskaya caves, all near Sochi, Krasnodar Prov., Russia (Golovatch, 1981, 1984/85; Golovatch, Enghoff, 1990). The above samples represent the first reliable records of the species from both Abkhazia and Crimea.

\section{Nopoiulus (Nopoiulus) ammonites Enghoff, 1984}

MATERIAL. 1 (IT), Russia, Krasnodar Prov., Mostovskoy Distr., Skalistyi Khrebet Mt. Range, 1.5 km NWW of Psebai, Ammonalnaya Cave, 21.III.2020; 1 (IT), same place, $2.3 \mathrm{~km}$ SWW of Besleneyevskaya, Besleneyevskaya I Cave, 25.I.2020; all P.V. Somchenko leg.

REMARKS. Narrowly endemic to caves in the same karst area, hitherto known only from the Ammonalnaya and Dedova Yama (= Dedova) caves, Mostovskoy Distr., Krasnodar Prov., Russia (Enghoff, 1984; Golovatch, Enghoff, 1990). This is a new, third record of this species, apparently a troglobite, this time from the Besleneyevskaya Cave, all three caves being located quite closely to one another.

Family Julidae Leach, 1814

\section{Cylindroiulus horvathi (Verhoeff, 1897)}

MATERIAL. $1 \sigma^{7}$ (ZMUM), Crimea, region of Sevastopol, western spurs of Ai-Petri Yayla Mt. Range, Mount Baltshik-Kaya, Uparennaya Cave, 17.III.2014; 1 +, 1 juv. (IT), Crimea, Bakhchisarai Distr., northwest spurs of Ai-Petri Yayla Mt. Range, Karadag Forest Area, Kristalnaya (=Imeni Maksimovicha) Cave, 6.X. 2020; all I.S. Turbanov leg.
REMARKS. An Eastern European to eastern Mediterranean species reported from Romania, Hungary, Bulgaria, Poland, Serbia, and Crimea (Korsós, Read, 1994; Jovanović, Antić, 2015). It has already been recorded (as C. ponticus Golovatch, 1978, a junior synonym (Korsós, Read, 1994)) from three places in Crimea, including the entrance to the Krasnaya (= Kyzyl-Koba) Cave (Golovatch, 1978; Golovatch et al., 2008, 2017). Apparently, this is a trogloxene.

\section{Leucogeorgia rediviva Golovatch, 1983}

MATERIAL. 2 O$^{\top} \sigma^{\top}, 3$ + 3 (ZMUM), Abkhazia, Gudauta Distr., Bzyb Mt. Range, Banka Cave (Snezhnaya cave system), Khrustalnyi Meandr gallery, $-570 \mathrm{~m}$ depth, in or near creek, 22.VIII.2017; 1 q (ZMUM), same cave, $-100 \mathrm{~m}$ depth, 25.VIII.2017; 2 ○ $\sigma^{7}, 3$ ㅇ (ZMUM), same place, Snezhnaya Cave, Revushchiye Kaskady, $-1530 \mathrm{~m}$ depth, near water, 23.VIII. 2017; all I.S. Turbanov leg.

REMARKS. Narrowly endemic to several caves in central Abkhazia, apparently a troglobite (Golovatch, 1983; Antić, Reip, 2020). This species has already been recorded from the Snezhnaya cave system (Antić, Reip, 2020).

\section{Megaphyllum tauricum (Attems, 1907)}

MATERIAL. $1 \sigma^{r}, 3$ ㅇ (ZMUM), Crimea, region of Sevastopol, western spurs of Ai-Petri Yayla Mt. Range, north side of Mount Forosskiy Kant, Yegerskaya II Cave, 20.V.2011; $2 \sigma^{7} \sigma^{7}, 1$ o (ZMUM), Crimea, Bakhchisarai Distr., northwest spurs Ai-Petri Yayla Mt. Range, Karadag

Figs 1-4. Some millipedes in caves of the Caucasus and Crimea. 1 - live Nopoiulus (Nopoiulus) kochii (Gervais, 1847), $0^{7}$ from Mikhailovskaya (= Shromskaya, Sukhumskaya, Stalaktitovaya) Cave, Abkhazia; 2 - live Syrioiulus kovali (Golovatch, 2008), $q$ from Tshernoretshenskaya Cave, Crimea; 3 - live Polydesmus (Polydesmus) abchasius Attems, 1898, ○7 from Anuchvinskaya (= Past' Tigra) Cave, Abkhazia; 4 - live Caucasodesmus turbanovi Golovatch et VandenSpiegel, 2015, $0^{7}$ from Tuakskaya (= Ful-Koba) Cave, Crimea. Photographs by I.S. Turbanov.

Рис. 1-4. Некоторые двупарноногие многоножки в пещерах Кавказа и Крыма. 1 - прижизненная фотография Nopoiulus (Nopoiulus) kochii (Gervais, 1847), О7 из пещеры Михайловская (= Шромская, Сухумская, Сталактитовая), Абхазия; 2 - прижизненная фотография Syrioiulus kovali (Golovatch, 2008), 9 из пещеры Чернореченская, Крым; 3 - прижизненная фотография Polydesmus (Polydesmus) abchasius Attems, 1898, О7 из пещеры Анухвинская (= Пасть Тигра), Абхазия; 4 - прижизненная фотография Caucasodesmus turbanovi Golovatch et VandenSpiegel, 2015, О7 из пещеры Туакская (= ФулКоба), Крым. Фотографии И.С. Турбанова. 
Forest Area, Kristalnaya (= Imeni Maksimovicha) Cave, 1.V.2013; 2 juv. (IT), same cave, 6.X.2020; all I.S. Turbanov leg.

REMARKS. Endemic to Crimea (Lazányi, Vagalinski, 2013), already recorded, albeit without exact location, from caves in Mountainous Crimea (Golovatch et al., 2017) based on the above material.

Omobrachyiulus caucasicus (Karsch, 1881)

MATERIAL. $1+$ (ZMUM), Russia, Chechnya, Shatoy Distr., $7.7 \mathrm{~km} \mathrm{~S}$ of Ulus-Kert, right bank of Sharo-Argun River, Camila (= CamilaKhyekh) Cave, 15.X.2019, S.A. Kapralov leg.

REMARKS. This widespread and common eastern Mediterranean species, often referred to as Omobrachyiulus brachyurus (Attems, 1899), its junior synonym (Vagalinski, Golovatch, in preparation), is subendemic to the Caucasus, known from Russia, Georgia, Armenia, Azerbaijan, Iran, Turkey and Greece (Vagalinski, Lazányi, 2018). Recorded as Megaphyllum (Omobrachyiulus) brachyurum thassensis Mauriès, 1985 from the Drakotrypa Cave, Thasos Island, Greece (Mauriès, 1985). The above sample represents the first record of the species from a cave in Russia, apparently a trogloxene.

\section{Pachyiulus krivolutskyi Golovatch, 1977}

MATERIAL. 1 (ZMUM), Abkhazia, Ochamchira Distr., near Otap, Samshitovaya Cave, 21.VIII.2015;2 우 (ZMUM), same place, Uatapachy (= Kolodets nad Golovoy Otapa) Cave, 24.VIII.2015; 1 O$^{7}$ (ZMUM), same place, Marshania Cave, 12.XI.2014; all I.S. Turbanov leg.

REMARKS. This species is the largest in size in the entire Caucasus, endemic to its western part: Russia, Abkhazia and Georgia (Evsyukov, 2016). It has been recorded from the Cave Ushchelnaya (= Pionerskaya) near Sochi, and a nameless grotto near Novorossiysk, Krasnodar Prov., Russia (Golovatch, 1984/85). The above samples represent the first reports of the species from caves in Abkhazia.

\section{Pachyiulus flavipes (C.L. Koch, 1847)}

MATERIAL. 1 フ , 3 우, 2 juv. (ZMUM), Crimea, region of Sevastopol, western spurs of Ai-Petri Yayla Mt. Range, north side of Mount Forosskiy Kant, Yegerskaya II Cave, 20.V.2011; $1 \bigcirc^{7}$ (ZMUM), Crimea, region of Sevastopol, western spurs of Ai-Petri Yayla Mt. Range, Mount Biyuk-Sinor, Sakhtykh Cave, 26.VIII. 2012; 1 \& (ZMUM), Crimea, Bakhchisarai Distr., northwest spurs Ai-Petri Yayla Mt. Range, Karadag Forest Area, Kristalnaya (= Imeni Maksimovicha) Cave, 1.V.2013; all I.S. Turbanov leg.

REMARKS. A widespread eastern Mediterranean species, often synanthrope (Mauriès et al., 1997; Frederiksen et al., 2012). It has been recorded from caves, albeit without exact location, in Crimea (Golovatch et al., 2017) based on the above samples, apparently a trogloxene.

Syrioiulus kovali (Golovatch, 2008)

Fig. 2.

MATERIAL. $2 \sigma^{\top} \sigma^{\top}, 1+$ (ZMUM), Crimea, region of Sevastopol, Baydarskaya Valley, near Rodnikovskoye, Skelskaya Cave, 4.III.2018; 2 $O^{\top} \bigcirc^{\top}, 3$ 우 (IT), same cave, 29.IX.2019, all I.S. Turbanov, A.A. Turbanova leg.; 1 क (IT), Crimea, region of Sevastopol, canyon of Tshernaya River, Tshernoretshenskaya Cave, 14.I.2020; 1 juv. (IT), Crimea, region of Sevastopol, western spurs of Ai-Petri Yayla Mt. Range, Mount Mortsheka, Druzhba Cave, 3.X.2020, I.S. Turbanov leg.

REMARKS. Endemic to southwestern Crimea, a troglobiont known only from a number of caves in the Ai-Petri, Baydarsko-Balaklavsky and Bakhchysarai karst massifs (Golovatch, 2008; Golovatch et al., 2017; Turbanov et al., 2018). The Tshernoretshenskaya Cave is a new locality for the species.

\section{Syrioiulus sp.}

MATERIAL. 1 (ZMUM), Crimea, Belogorsk Distr., SE spurs of Karabi Yayla Mt. 
Range, near Tshigenitra Pass, Tuakskaya (=FulKoba) Cave, 16.VII.2016, I.S. Turbanov leg.

REMARKS. To identify this species, $\sigma^{7}$ material must be collected and studied. This is the first record of the genus Syrioiulus Verhoe$\mathrm{ff}, 1914$ in caves in the eastern part of Mountainous Crimea.

Order Polydesmida Leach, 1815

Family Paradoxosomatidae Daday, 1889

Strongylosoma kordylamythrum Attems, 1898

MATERIAL. $4 \bigcirc^{7} \sigma^{7}, 7$ 7 , 2 juv. (ZMUM), Abkhazia, Ochamchira Distr., near Otap, Golova Otapa Cave, in bat guano, 8.IX.2014; $2 \mathrm{O}^{\top} \mathrm{O}^{\top}$, 2 우, 4 juv. (ZMUM), Abkhazia, Ochamchira Distr., near Thina, Thinskaya Cave, in bat guano, 10.IX.2015; 2 ○ $^{7}, 1$ \&, 2 juv. (ZMUM), Abkhazia, Sukhum Distr., near Verkhnie Eshery, Adzaba Cave, in bat guano, 14.IX.2014; 3 $\mathrm{O}^{7} \mathrm{O}^{7}, 1$ ( 1 (ZMUM), Abkhazia, Gudauta Distr., near Anuchva, Anuchvinskaya (= Past' Tigra) Cave, 11.IX.2015; 1 O (ZMUM), Abkhazia, Gudauta Distr., Duripsh, Duripshskaya Vodyanaya Cave, 29.VIII.2017; 1 + (ZMUM), same place, Lakerbaya Cave, 27.III.2017; all I.S. Turbanov leg.

REMARKS. An eastern Mediterranean species subendemic to the Caucasus: Russia, Abkhazia, Georgia, Turkey, Azerbaijan and Iran. It has been recorded as a troglophile in a number of caves: Psebe Cave, Tuapse Distr.; Shirokopokosskaya and Labirintovaya (= Bozhyey Materi, Our Lady) caves near Sochi; Ammonalnaya Cave, Mostovskoy Distr., Krasnodar Province (Evsyukov et al., 2016). The above samples represent the first records of this species from caves in Abkhazia.

Family Polydesmidae Leach 1815

$$
\begin{gathered}
\text { Polydesmus (Polydesmus) abchasius } \\
\text { Attems, } 1898
\end{gathered}
$$

Fig. 3.

MATERIAL. 1 ○ (ZMUM), Abkhazia, Gudauta Distr., near Anuchva, Anuchvinskaya
(= Past' Tigra) Cave, 11.IX.2015, I.S. Turbanov leg.

REMARKS. Endemic to the western and central Caucasus: Russia, Abkhazia and Georgia. It has been recorded from the Nikortsminda Cave, Ambrolauri Distr., Georgia (Golovatch et al., 2016). Apparently a trogloxene, the above sample representing the first record of this species from caves in Abkhazia.

\section{Polydesmus (Nomarchus) mediterraneus Daday, 1889}

MATERIAL. $1 \sigma^{\top}$ (ZMUM), Crimea, Bakhchisarai Distr., northeastern spurs of the AiPetri Yayla Mt. Range, Bash-Dere Area, Avantyura Cave, 15.XI.2014, I.S. Turbanov leg.

REMARKS. An eastern Mediterranean species: the Balkans and Romania, obviously introduced to Crimea and the Caucasus (Abkhazia) (Golovatch, 1978; Golovatch et al., 2016). It was recorded from the Skelskaya Cave, Crimea (Golovatch, 1978), while the above new sample represents a new locality in Crimea; apparently a trogloxene.

\section{Brachydesmus furcatus Lohmander, 1936}

MATERIAL. $1 \sigma^{\top}$ (ZMUM), Russia, Krasnodar Province, Apsheronsky Distr., NE spurs of Lago-Naki Mt. Range, Azish-Tau Mt. Ridge, Piketnaya Cave, 6.XI.2020, I.S. Turbanov leg.

REMARKS. Endemic to the western Caucasus: Russia and Abkhazia [Golovatch et al., 2016], also encountered as a troglophile in a few caves: Akhunskaya, Fanagoriyskaya, Medvezhya and Baribana, all within the Krasnodar Prov., Russia (Strasser, 1970; Golovatch et al., 2016, 2018).

\section{Brachydesmus jubatus Attems, 1907}

MATERIAL. $1 \sigma^{7}, 11$ juv. (ZMUM), Crimea, region of Sevastopol, Baydarskaya Valley, near Kizilivoye, Mamut-Tshokrak Cave, 14.V.2011; $1 \mathrm{O}^{7}, 2$ of, 2 juv. (ZMUM), Crimea, region of Sevastopol, Baydarskaya Yayla Mt. Range, Donguz-Orun Ridge, Zelenykh Kamneyedov Cave, 27.V.2011; all I.S. Turbanov. 
REMARKS. A circum-Pontic species known from the Rostov-on-Don Region of Russia, Crimea, northern Turkey and eastern Romania (Evsyukov, Golovatch, 2013). It was recorded, albeit without exact locality, from caves in Crimea (Golovatch et al., 2017), apparently as a troglophile and at least in part based on the above samples.

Family Trichopolydesmidae Verhoeff, 1910

\section{Caucasodesmus turbanovi Golovatch et VandenSpiegel, 2015}

Fig. 4.

MATERIAL. 2 우 (ZMUM), $1 \sigma^{\top}, 2$ 우 (IT), Crimea, Belogorsk Distr., southeastern spurs of the Karabi Yayla Mt. Range, near Chigenitra Pass, Tuakskaya (=Ful-Koba) Cave, 16.VII.2016, I.S. Turbanov leg.

REMARKS. Endemic to a cave in Mountainous Crimea, hitherto known as a troglobite only from the Tuakskaya (= Ful-Koba) Cave (Golovatch, VandenSpiegel, 2015). Above is a strictly topotypic material.

\section{Caucasodesmus svetlanae Golovatch et VandenSpiegel, 2015}

MATERIAL. $1+$ (ZMUM), Crimea, region of Sevastopol, Baydarskaya Valley, near Rodnikovskoye, Skelskaya Cave, 4.III.2018; $1 O^{\top}, 1$ q (IT), same cave, 29.IX.2020; all I.S. Turbanov, A.A. Turbanova leg.

REMARKS. Endemic to caves in the southwestern part of Mountainous Crimea (Golovatch, VandenSpiegel, 2015; Turbanov et al., 2018). This troglobiont species has already been recorded from the Skelskaya Cave (Turbanov et al., 2018).

\section{Discussion}

Despite several recent review papers devoted to the cave millipede fauna of the regions concerned (Golovatch, 1984/85; Turbanov et al., 2016; Golovatch et al., 2018; etc.), the question of an ecological classification of the cave-dwelling Diplopoda remains open. Above, under each species account, we applied the classical classification that divides the subterranean fauna into three categories only: trogloxenes, troglophiles, and troglobionts (Vandel, 1964). Below we attempt to classify the above records from an ecological viewpoint using an even more advanced ecological classification by Boris Sket (2008), based on which it appears possible to delimit the following four categories as applied to Diplopoda: (1) troglobiont is a species or population strictly bound to a hypogean habitat; (2) eutroglophile is an essentially epigean species, but capable of maintaining a permanent subterranean population; (3) subtroglophile is inclined perpetually or temporarily to inhabiting a subterranean habitat, but is bound to the surface for some biological functions (e.g. feeding); (4) trogloxene is a species only occurring sporadically (accidentally) underground.

We refer the following diplopod species to the group of troglobionts: Nopoiulus (N.) ammonites, Leucogeorgia rediviva, Syrioiulis kovali, Caucasodesmus turbanovi and C. svetlanae. These millipedes are known only from caves and show well-defined troglomorphies. Conditionally, ?Typhloglomeris spp. may also join this group, but it seems noteworthy that one of the two troglomorphic species of Typhloglomeris in the Caucasus, T. caucasica, has been found epigeically and thus treated as an eutroglophile (Golovatch, Chumachenko, 2013). In contrast, the likewise troglomorphic $T$. palatovi Golovatch et Turbanov, 2018, from the Chortskhu Cave in western Georgia, is considered to represent a troglobiont (Golovatch, Turbanov, 2018).

Both Nopoiulus (N.) kochii and Strongylosoma kordylamythrum can be attributed to the group of eutroglophiles as well, because even though being epigean, they are capable of maintaining stable and self-reproducing underground populations. The repeated records of S. kordylamythrum on bat guano inside caves are noteworthy, the collections often covering various developmental stadia.

Both Trachysphaera costata and Brachydesmus jubatus seem to belong to the group of 
subtroglophiles, epigean species using caves for certain life purposes, e.g., hibernation and/ or aestivation, and/or suitable food resources.

All remaining species of Diplopoda recorded above seem to represent the group of trogloxenes: Polyxenus argentifer, Hyleoglomeris specialis, Hirudisoma roseum, Cylindroiulus horvathi, Megaphyllum tauricum, Omobrachyiulus caucasicus, Pachyiulus krivolutskyi, P. flavipes, Polydesmus abchasius, and $P$. mediterraneus. These dipopods are typical epigean species that enter the caves often accidentally (e.g., falling down vertical wells) and usually die to serve as part of the allochthonous organic matter thereafter.

\section{Compliance with ethical standards}

CONFLICTS OF INTEREST: The authors declare that they have no conflicts of interest.

Acknowledgments. We are most grateful to Alexander P. Evsyukov (Don State Technical University, Rostov-on-Don, Russia) for his critical review of an advanced draft. The first author was partly supported by the Presidium of the Russian Academy of Sciences, Programme No. 41 "Biodiversity of natural systems and biological resources of Russia". Ilya $\mathrm{S}$. Turbanov performed his study in the framework of a state assignment (topics No. AAAAA18-118012690105-0, AAAA-A18118012690106-7).

\section{References}

Antić D.Ž., Makarov S.E. 2016. The Caucasus as a major hotspot of biodiversity: Evidence from the millipede family Anthroleucosomatidae (Diplopoda, Chordeumatida) // Zootaxa. Vol.4211. No.1. P.1-205.

Antić D.Ž., Reip H.S. 2020. The millipede genus Leucogeorgia Verhoeff, 1930 in the Caucasus, with descriptions of eleven new species, erection of a new monotypic genus and notes on the tribe Leucogeorgiini (Diplopoda: Julida: Julidae) // European Journal of Taxonomy. Vol.713. P.1-106.

Antić D.Ž., Turbanov I.S., Reboleira P.S.A.S. 2018. From the depths: Heterocaucaseuma deprofundum sp. nov., the world's deepest records of a millipede (Diplopoda, Chordeumatida, Anthroleucosomatidae) from the western Caucasus // Zootaxa. Vol.4377. No.1. P.110-124.

Barjadze S., Murvanidze M., Arabuli T., Mumladze L., Pkhakadze V., Djanashvili R., Salakaia M. 2015.
Annotated list of invertebrates of the Georgian karst caves. Tbilisi: Georgian Academic Book. 120 pp.

Barjadze Sh., Asanidze Z., Gavashelishvili A., SotoAdames F.N. 2019. The hypogean invertebrate fauna of Georgia (Caucasus) // Zoology in the Middle East. Vol.65. No.1. P.1-10.

Enghoff H. 1984. A revision of the Nopoiulinae, with notes on the classification of blaniulid millipedes (Diplopoda: Julida: Blaniulidae) // Senckenbergiana biologica. Bd.64. H.4/6. S.393-427.

Evsyukov A.P. 2016. The millipede Pachyiulus krivolutskyi Golovatch, 1977, the easternmost species of the eastern Mediterranean genus Pachyiulus Berlese, 1883, endemic to the western Caucasus (Diplopoda: Julida: Julidae) // Russian Entomological Journal. Vol.25. No.3. P.299-306.

Evsyukov A.P., Golovatch S.I. 2013. Millipedes (Diplopoda) from the Rostov-on-Don Region, southern Russia // Arthropoda Selecta. Vol.22. No.3. P.207-215.

Evsyukov A., Golovatch S., Reip H.S. 2016. The millipede genus Strongylosoma in the Caucasus (Diplopoda: Polydesmida, Paradoxosomatidae) // Acta Societatis Zoologicae Bohemicae. Vol.80. P.7-16.

Evsyukov A., Golovatch S., Reip H.S. 2018. The millipede genus Julus Linnaeus, 1758 in the Caucasus (Diplopoda: Julida: Julidae) // Zootaxa. Vol.4461. No.1. P.89117.

Evsyukov A., Golovatch S., Reip H., VandenSpiegel D. 2020. The millipede tribe Leptoiulini in the Caucasus, with notes on its generic classification (Diplopoda: Julida: Julidae) // Zootaxa. Vol.4778. No.2. P.237280 .

Frederiksen S.B., Petersen G., Enghoff H. 2012. How many species are there of Pachyiulus? A contribution to the taxonomy of Europe's largest millipedes (Diplopoda: Julida: Julidae) // Journal of Natural History. Vol.46. Nos 9-10. P.599-611.

Golovatch S.I. 1975. [Two genera of Oniscomorpha new to the USSR fauna (Diplopoda), found in Transcaucasia, and their zoogeographical relations] // Zoologicheskii zhurnal. Vol.54. No.10. P.1566-1671 [in Russian, with English summary].

Golovatch S.I. 1978. [New or poorly-known species of Diplopoda from the European part of the USSR] // Zoologicheskii zhurnal. Vol.57. No.3. P.453-457 [in Russian, with English summary].

Golovatch S.I. 1981. [A review of the cave fauna of Diplopoda of the western Caucasus] // [Peshchery Gruzii]. No.10. P.108-111 [in Russian].

Golovatch S.I. 1983. Une nouvelle espèce cavernicole du genre Leucogeorgia de la Transcaucasie (Diplopoda, Julidae) // Fragmenta Entomologica. Vol.17. No.1. P.47-50.

Golovatch S.I. 1984/85. Two new genera of cave-dwelling millipedes (Diplopoda), with remarks on the millipede fauna of West Caucasian caves // International Journal of Speleology. Vol.14. P.39-50.

Golovatch S.I. 1989a. Diplopoda of the Caucasus, 1. Glomeridellidae, with contributions to the fauna of Turkey // Senckenbergiana biologica. Bd.69. H.4-6. 
P.405-419.

Golovatch S.I. 1989b. Diplopoda of the Caucasus, 2. Glomeridae, with contributions to the fauna of Turkey // Senckenbergiana biologica. Bd.69. H.4-6. P.421-440.

Golovatch S.I. 1990. Diplopoda of the Caucasus, 3. Trachysphaeridae, with contributions to the fauna of Turkey // Senckenbergiana biologica. Bd.70. H.4-6. P.331358.

Golovatch S.I. 2008. On three remarkable millipedes (Diplopoda) from the Crimea, Ukraine // International Journal of Myriapodology. Vol.1. P.97-110.

Golovatch S.I. 2010. The millipede genus Trachysphaera Heller, 1858 in the Ukraine (Diplopoda: Glomeridae) // Arthropoda Selecta. Vol.19. No.1. P.1-5.

Golovatch S.I., Chumachenko Y.A. 2013. The millipede Typhloglomeris caucasica Golovatch, 1975 found epigeically (Diplopoda, Glomerida, Glomeridellidae) // Biodiversity Data Journal. Vol.1. No. e981. P. 1-3. https://doi.org/10.3897/BDJ.1.e981

Golovatch S.I., Enghoff H. 1990. [The millipede Nopoiulus kochii (Gervais, 1847) in the Caucasus (Diplopoda, Julida, Blaniulidae)] // Striganova B.R. (ed.), Fauna nazemnykh bespozvonochnykh Kavkaza. Moscow: Nauka. P. 114-118 [in Russian, with English summary].

Golovatch S., Evsyukov A., Reip H.S. 2015. Colobognatha millipedes in the Caucasus (Diplopoda: Polyzoniida, Platydesmida, Siphonocryptida) // Zootaxa. Vol.3972. No.2. P.250-266.

Golovatch S., Evsyukov A., Reip H.S. 2016. The millipede family Polydesmidae in the Caucasus (Diplopoda: Polydesmida) // Zootaxa. Vol.4085. No.1. P.1-51.

Golovatch S.I., Palatov D.M., Turbanov I.S., Kniss V.A., Gazaryan S., Snit'ko V.P., Decu V., Juberthie Ch., Nazareanu G. 2018. Subterranean biota of the European part of Russia: A review // Invertebrate Zoology. Vol.15. No.2. P.153-213.

Golovatch S.I., Turbanov I.S. 2018. A new cavernicolous species of the millipede genus Typhloglomeris Verhoeff, 1898 from western Georgia, Caucasus (Diplopoda: Glomerida: Glomeridellidae) // Russian Entomological Journal. Vol.27. No.1. P.101-104.

Golovatch S.I., Turbanov I.S., VandenSpiegel D. 2017. Contributions to the cave millipede fauna of the Crimean Peninsula (Diplopoda), with the description of a new species // Arthropoda Selecta. Vol.26. No.2. P.103-111.

Golovatch S.I., VandenSpiegel D. 2015. Two new species of the millipede genus Caucasodesmus Golovatch, 1985 from the Crimea, Russia (Diplopoda, Polydesmida, Trichopolydesmidae) // Russian Entomological Journal. Vol.24. No.1. P.1-6.

Jovanović Z.S., Antić D.Ž. 2015. First record of Cylindroiulus horvathi (Diplopoda, Julida, Julidae) in Ser- bia // Kragujevac Journal of Science. Vol.37. P.143148.

Kokhia M.S., Golovatch S.I. 2020. Diversity and distribution of the millipedes (Diplopoda) of Georgia, Caucasus // ZooKeys. Vol.930. P.199-219.

Korsós Z., Read H.J. 1994. Revision of the horvathi group and description of a new species of Cylindroiulus (Diplopoda: Julidae) // Journal of Natural History. Vol.28. No.4. P.841-852.

Lazányi E., Vagalinski B. 2013. Redefinition of the millipede subgenus Megaphyllum sensu stricto Verhoeff, 1894 and neotype designation for Megaphyllum austriacum (Latzel, 1884) (Myriapoda: Diplopoda: Julida: Julidae) // Zootaxa. Vol.3741. No.1. P.55-100.

Mauriès J.-P. 1985. Les Diplopodes récoltés en 1982 par $\mathrm{P}$. Beron et $\mathrm{S}$. Andreev dans l'île de Thasos (Grèce). Thassoblaniulus, nouveau genre de Blaniulide (Blaniulinae) // Acta Zoologica Bulgarica. Vol.1 No.5. P.52-59.

Mauriès J.-P., Golovatch S.I., Stoev P. 1997. The millipedes of Albania: Recent data, new taxa; systematical, nomenclatural and faunistical review (Myriapoda, Diplopoda) // Zoosystema. Vol.19. Nos 2-3. P.255292.

Pliginsky V.G. 1927. [On the fauna of Crimean caves. Communication 3] // Russkoye entomologicheskoe obozrenie. Vol.21. No.3-4. P.171-180 [in Russian].

Short M., Vahtera V., Wesener T., Golovatch S.I. 2020. The millipede family Polyxenidae (Diplopoda, Polyxenida) in the faunas of the Crimean Peninsula and Caucasus, with notes on other European Polyxenidae // Zootaxa. Vol.4772. No.2. P.306-332.

Sket B. 2008. Can we agree on an ecological classification of subterranean animals? // Journal of Natural History. Vol.42. Nos 21-22. P.1549-1563.

Turbanov I.S., Palatov D.M., Golovatch S.I. 2016. [The state of the art of biospeleology in Russia and other countries of the former Soviet Union: A review of cave (endogean) invertebrate fauna. 2. Arachnida - Acknowledgements] // Zoologicheskii zhurnal. Vol.95. No.11. P.1283-1304 [in Russian; English translation: Entomological Review. 2016. Vol.96. No.9. P.12971333].

Turbanov I.S., Golovatch S.I., VandenSpiegel D. 2018. New interesting records of three cavernicolous millipede species from the Crimean Peninsula // Arthropoda Selecta. Vol.27. No.3. P.201-209.

Vagalinski B., Lazányi E. 2018. Revision of the millipede tribe Brachyiulini Verhoeff, 1909 (Diplopoda: Julida: Julidae), with descriptions of new taxa // Zootaxa. Vol.4421. No.1. P.1-142.

Vandel A. 1964. Biospéologie. La biologie des animaux cavernicoles. Paris: Gauthier-Villars. xviii +619 p.

Responsible editor K.G. Mikhailov 